\title{
Mentoring EFL Teaching During the Covid-19 Pandemic
}

\author{
Nafan Tarihoran, Universitas Islam Negeri Sultan Maulana Hasanuddin Banten, \\ nafan.tarihoran@uinbanten.ac.id \\ Muhammad Farkhan, Universitas Islam Negeri Syarif Hidayatulah Jakarta, farkhan@uinjkt.ac.id \\ Hunainah, Universitas Islam Negeri Sultan Maulana Hasanuddin Banten, hunainah@uinbanten.ac.id
}

\begin{abstract}
The Corona Virus (Covid-19) has affected almost all aspects of life, including the mentoring English Foreign Language (EFL) teachers. Teaching practice has been increasingly emphasized as a vital part of preservice teacher training program. During the Covid-19, there were a number of initiatives to assist teachers in education program. Between these, online mentoring via social media platforms are rapidly emerging as a creative approach to assist preservice teacher with additional resources. The study aimed at exploring the effectiveness of online mentoring during the COVID-19 Pandemic. Data were 24 preservice teachers and 4 mentors participated in this study at the Faculty of Islamic Education and Teacher Training in Banten. Mixed method designs a survey method and interview conducted online. The study analysed the effect of online mentoring experience differences on preservice teachers of mentoring activities. This study also explained kinds of mentoring used during the Covid-19 pandemic. It can be concluded that online learning was effective because the conditions that required online study and the mentor-mentee talk as not as effective as in the normal mentoring. The results of the study have implications for mentors, preservice teacher, and administrators. Supports from institution and schools are needed for the success of online mentoring
\end{abstract}

Keywords: Covid-19 pandemic, EFL teaching, online mentoring, preservice teacher

Received: 09.11.2020 Accepted: 15.12.2020 Published: 05.01.2021

\section{INTRODUCTION}

The COVID-19 pandemic is an evolving disease with a major impact on the education system. As a response to this issue, most academic heads now support online education. Educational institutions face decisions about how to continue teaching and learning processes while shielding their lecturers and students from a rapid and not well known public health emergency (UNESCO, 2020). Many online learning opportunities and full degree programs are provided by educational institutions. Learning and teaching methods are evolving, suggesting the nature of student learning experiences (Demuyakor, 2020).

The conventional approach to teaching moved from the lecturer to the student to the student core. This satisfies the steady growth in enrolment in online learning. Many universities have agreed to cancel all face-to- face classes and other opportunities for learning and have forced universities to transfer their courses online to avoid the spread of viruses by COVID-19 (Murphy, 2020; Yulia, 2020). The number of higher education institutions implementing this decision has grown. State universities and schools, like Islamic universities in Indonesia, pass their classes online in all sizes and ways (Fithra, 2020; Simamora, 2020).

The quality of educational systems is profoundly dependent on the participation and growth of outstanding teachers in classrooms. In (Pyne, 2014) state that "the quality of an education system cannot exceed the quality of its teachers (P.2)." The World Bank declared that improving the quality of teachers as one of the key mandates for improving education (World Bank, 2018). Teacher educations have support services to help first-year students adjust from school to university culture. In this context, mentoring can be a turning point for teachers in their professional development. The notion of mentoring seems to be gaining momentum into the teaching field. As a practice in education program, mentoring has taken many forms over the years (Hobson et al., 2009; Tomlinson, 1998). Mentoring during the COVIC-19 pandemic in Indonesia gives challenges and opportunities for preservice teachers and lecturers. Like numerous sectors of society, the Indonesian education system is also uneven, especially because of the coming COVID-19 pandemic. Online mentoring can be one of the answers for preservice teachers to make such measurements of their teaching-learning process in order to achieve the situation in which students can get it and understand what they are learning (Tuomikoski et al., 2020). Mentoring and induction programs are an increasingly popular activity in teacher training program (Darling-hammond et al., 2017; Smith \& Ingersoll, 
2004). The positive effects of induction programs on attrition rates have been verified by a large-scale study.

In the country of Indonesia, the education system is based on Islamic education and public education and requires students to attend regular classes at school. The use of online mentoring in the preservice classroom of teachers would have a positive impact on the future of teachers. Dudeney said that using technology in the school is becoming increasingly relevant and will become a daily part of EFL practice (Dudeney, G. and Hockly, 2008). Preservice teachers (PTs) should be better trained to teach with technology from the first day when they join the field. Curriculum in teacher education program, along with lecturer use of technology for teaching-learning, will impact the use of technology through teacher protection in future practice.

Even there are several studies investigated the mentoring English Foreign Language (EFL) teaching (Awaya et al., 2003; Izadinia, 2015; Mann \& Tang, 2012; Tasnim, 2020), but only a few researchers examined the preservice teachers' view in utilizing the technology in a particularized way during COVID19 pandemic.

\section{LITERATURE REVIEW}

\section{Mentoring in Higher Education}

Mentoring is often confused with coaching; however, coaching is only part of mentoring. Coaching is increasingly common as a strategy to support the professional development of teachers and as a tool to help manage change. It is typically a short-term affair, based either on building up or removing particular habits. A coach provides advice and suggestions and knows precisely when his job is over. Coaching is a human development mechanism that includes a framework that focuses on engagement and the use of appropriate methods, resources and techniques to facilitate beneficial progress that is effective for the benefit coaches that potentially for stakeholders (Cox et al., 2014).

Mentoring is well known in schools as support for trainee teachers, new teachers, and new roles and responsibilities (Wright, 2008). Mentoring, on the other hand, requires a long-term partnership where the primary aim is to promote the development of the mentee. The mentor should advise, educate and help without asking for concrete behavioral improvements or recommending a defined course of action.

Both coaching and mentoring are development strategies that use listening, questioning, clarifying and reframing skills, and share one-to-one conversations as the primary technique of interaction to strengthen the skills, knowledge or job performance of a person. On coaching and mentoring, (Bubb, 2005) points out that mentoring offers a wide variety of professional learning opportunities where coaching is limited to improving the unique skills and expertise needed in learning and teaching.

Traditionally, implicit in mentoring is the encouragement and guidance provided by a mentor who has the experience, expertise and qualities of a knowledgeable and trustworthy advisor, a person who has walked the path of the trainee and recognizes the challenges (Kutsyuruba \& Walker, 2020). As an expert, the instructor is there to educate, direct and use his or her greater understanding and expertise to help the trainee (Brandt et al., 2020).

Mentoring early teachers are often referred to as good practice. Many researchers believe that professional experiences, such as field experience, induction in school, is important for the creation of quality teachers in preparatory education programs. During practice teaching, mentoring has prominence in recent years since need to change the organization of the field experiences in teacher education program (Farrell, 2008; Hennissen et al., 2011). Providing a mentor to begin-up teachers means helping them and ensuring that they build up their professional experience, expertise and abilities. A mentor is typically a colleague with appropriate, school-specific experience. It also bridges the change between early education and full employment. In some cases, mentors can make decisions or provide proof that the new teacher has demonstrated the requisite professional competence.

Shannon (1998) defines mentoring is described as a nurturing process in which an accomplished individual befriends a person with fewer experiences or skills to encourage his or her personal and professional growth as cited in (Peterson et al., 1998). More details, Mentoring is a means of providing encouragement, challenge and extension of one person's learning through guidance to those who are more qualified, competent and experienced, especially in relation to the context in which learning takes place (Pollard \& Collins, 2005).

In the higher education context, mentoring can be a turning point for PTs at the Islamic university in their professional awareness. It has an important impact on early teaching experiences of preservice teachers (Delaney, 2012). Mentoring was needed to create a systematic effect on teaching-learning so that practicing teaching would become an effective professional teaching and learning experience for preservice teachers. (Hobson et al., 2009) explains the goals of mentoring to help mentees select theoretical 
orientations for their work in the classroom, helping them cross the theoretical-practical divide, and building up mentee knowledge and modelling skills in professional thought, learning and planning.

\section{The Role of Mentoring for EFL Preservice Teachers}

The ability for students to participate in meaningful educational learning opportunities is seen as important to any professional education. Teacher education institutions actively seek opportunities for the incorporation of improved practice-based professional experience. In doing so, students can explore the principle of connection practice and further improve their professional knowledge and skills. A significant aspect of this initiative is to find suitable ways to draw on the expertise and knowledge of those practitioners who are able to provide the necessary guidance and guidance needed.

Developing an online mentoring gaining of design or continuity of a learning interface is very much needed during a COVID-19 pandemic. Therefore, if a pandemic occurs in the future, a well-planned lesson plan is intended to increase and enhance online mentoring or online courses on a large scale. There has been an emphasis on mentoring as a one-way approach to delivering authentic learning opportunities under the wider definition of professional growth. Mentoring and the relationship that occurs between the mentor and the mentee helps to cultivate a young professional while recognizing the experiences and skills of established colleagues. While much of the literature that focuses on the mentoring relationship highlights its purpose and benefits to the mentor, it is also important to recognize the benefits to the mentor (Lacey, 1999). Such benefits have been described as the enhancement of self-esteem, the establishment of a strong relationship with the mentee, the ability to meet their own professional development needs, appreciation and altruistic fulfilment in the service of the profession.

Online Mentoring (OM) has pushed the limits of learning with various forms of learning Carpenter (Hyndman \& Harvey, 2020). Online mentoring is defined as learning which takes place in whole or in part over the Internet. Online mentoring suggested that mentee learning outcomes in classes are affected by the features of online course design, to some degree, online learning studies draw on the constructivist approach to learning that emphasizes learning experience reflection.

Inline to this statement, there has been increased interest in promoting student-centred learning among academics and policymakers. Online mentoring can help circumvent of these issues (Greenberg et al., 2016). For instance, (Kearsley \& Shneiderman, 1998) noted that the basic principle behind engagement theory is that students need to be meaningfully engaged in learning activities by communication with others and worthwhile tasks.

Online mentoring requires multiple ways of interaction between the various actors. An interaction is characterized as "a mutual action or effect of two objects, two persons." In pedagogy, this has been studied from many points of view and has given rise to different theories, adding a new dimension to the growth of online learning.

There are three kinds of online mentoring, namely, synchronous, asynchronous and blended learning (Carliner, 2004; and Carliner \& Shank, 2016). Online mentoring can also broaden the range of courses available to students, especially for students living in rural or inner cities. Many of these problems can be avoided by online mentorships (Greenberg et al., 2016) An interactive synchronous, asynchronous, technology-based solution offers a variety of positive ways to promote mentoring and reflexive and proactive multidimensional pedagogy by removing time and other constraints. In an evolving area of education, this approach also offers useful technical preparation, where integrated and online approaches help to build both productive peer-to - peer and peer-mentor dynamics.

Recent studies (Malanson et al., 2014; Owen \& Whalley, 2017) have established both strong advantages and complexities to be taken into account when introducing virtual mentorships. (Reese, 2016) explicitly introduced a virtual mentorship in a Program for Preservice Instruction, digital experiences were precious but distinct from conventional experiences of mentoring. The advantages were similar to those found by conventional mentorships, and some difficulties associated with face-to - face mentoring were alleviated by the use of technology, but the difficulties were broader than access and time; it was the failure of mentees and mentors to promote broader interactions and learning reflections.

It is important to note that preservice teachers become skilled teachers from higher education institutions that have to participate in an initial education training program. With the assistance and mentorship of university faculty, they complete supervised field-based teaching experiences. (Powell \& Mills, 1994) identify five types of mentoring among teachers. These types were collaborative mentoring, clerical mentoring, professional teacher mentoring, interdisciplinary content mentoring, and social informal mentoring. Some terms related to mentoring can be seen in table 1. 
Table 1. Mentoring Terms

\begin{tabular}{|l|l|}
\hline Terms & Keywords \\
\hline Mentoring & Mentor and mentee or advisor \\
\hline Peer mentoring & "peer" \\
\hline Graduate mentoring & Graduate or postgraduate or doctoral \\
\hline Teacher mentoring & Faculty or instructor or principle \\
\hline
\end{tabular}

Overall, the philosophy behind educational engagement and mentorship, and especially with preserve teaches, emphasizes the importance of creating communicative spaces in which new teachers can openly interact with an experience mentor. Online mentoring is a way to have a driven mentoring relationship through online software or learning management system. It allows participants to interact at their convenience and beyond time zones, as it eliminates the need for them to be in the same physical location.

Teaching practice has been identified as one of the most critical elements of the Teacher Education Curriculum for Teachers (Funk et al., 1982). During the mentoring, the teacher is socialized in all facets of the teaching career, both within and outside the classroom, and has been well studied in general education. However, in teaching English as a foreign language (EFL), there is a lack of such research relevant to the unique experience of mentor-mentee during their teaching practice.

Teaching EFL has a very significant role to play in the realities of language teaching and learning. Machines who need to know not only how to use it, but also how beneficial it can be, are in the hands of preservice teachers. In addition, the choice of specific teaching materials indicates that an extremely skilled, political and indeed budgetary undertaking exists as an official educational option (Riazi, 2003).

EFL's educational materials contain 'realia' and are very important representations and instructional devices (such as overhead projectors, tape recorder, video and multimedia). Of course, they can be used efficiently for language instruction, which explicitly deals with the use of visual aids (Devies, 2002). The teaching and learning process of English will be more student-centered, the standard of teaching will be increased, and the related English skills of students will be built viably (Shyamlee \& Phil, 2012).

Moreover, in most language programs, (Malderez \& Wedell, 2007) describe five main roles that mentor should ideally fulfil, as seen in Table 2 . These five roles are congruent with ones expected of mentor in Indonesia.

Table 2. the Roles of Mentor

\begin{tabular}{|l|l|}
\hline Type of Mentor & \multicolumn{1}{|c|}{ The Roles } \\
\hline Acculturator & $\begin{array}{l}\text { One who help the newcomer become a legitimate } \\
\text { peripheral participant in the school's community. }\end{array}$ \\
\hline Support & $\begin{array}{l}\text { One a trusting relationship has been established } \\
\text { between mentor and mentee. }\end{array}$ \\
\hline Model & $\begin{array}{l}\text { Not to be understood as a model to be emulated } \\
\text { but as a model of enthusiasm for the job. }\end{array}$ \\
\hline Sponsor & When mentor intercedes on the mentee's behalf. \\
\hline Education & The actual learning expected of learner. \\
\hline
\end{tabular}

Along similar lines, Three EFL Classroom technology and resource selection guidelines: 1) Students need feedback on learning English. 2) English, used for many different purposes, in many distinct forms. 3) By selecting the right vocabulary and arranging the learning exercises, the teacher can provide guidance (Chapelle \& Jamieson, 2008).

As students live in the digital era, requirements are being made for almost all of them, including preservice teachers, to become technologically educated. Teachers may also use computer programs to build materials for English Foreign Language (EFL) students, but they may be overwhelmed by the technology, and computers are increasingly used by students.

\section{Corona Virus (COVID-19)}

Coronavirus contains viruses which have a single strand of ribonucleic acid in their genome. Health experts are worried about coronavirus, which has infected/killed thousands of people(Yang et al., 2020). This disease is part of the pathogen family that causes severe acute respiratory syndrome (SARS) that another person can easily touch. 
In December 2019, this virus originated in a Chinese town, Wuhan. The Chinese authority has issued a travel ban in and out of the affected Chinese cities to control the outbreak of the disease. The affected communities have criticized this lockdown as a wrong decision due to psychological consequences resulting from demanding access to medical assistance, supplies or materials (Abere, 2020).

It may spread from animal to human, or from person to person, or be contacted. As a result, Soumya Swaminathan, the Chief Scientist at W.H.O in Switzerland, has officially named disease caused by this coronavirus as COVID-19 (that is, coronavirus disease 2019). This is to differentiate past or potential outbreaks of this disease from other coronaviruses. The researchers at South China Agricultural University Guangzhou, on February 7, 2020, indicated in a press conference that an animal species (pangolin) is the cause of the disease outbreak. This was due to the animal's genetic similarity with the individual infected. Pangolins are animals which are sometimes used in Chinese local medicine(Gross, 2020).

On 30 January 2020, W.H.O Director-General Tedros G. Adhanom declared the outbreak of this disease a global health emergency because it could be epidemic and devastating to countries with inadequate healthcare facilities, (He et al., 2020),(W.H.O, 2020). The global health emergency declaration will gear experts up to probe the infection biology, develop drug/vaccine and weigh up the worst-case scenario. A study at Schenzhen in China showed that some infected persons with the virus were not exhibiting any symptoms of the disease. This makes this virus deadly as it can be contacted without knowing by someone carrying the disease without showing signs. Within a very short time of novel coronavirus emergence, many papers/articles had been written on it. However, these were based on survey reports rather than empirical studies, and the role of explanatory factors was not adequately investigated. In this respect, the current study highlights how participants define each other's role and extent to which they meet expectations from mentoring practices during COVIC-19.

Although the research is focused on previous literature studies, it differs in a variety of ways. Firstly, it reflects on the ways in which mentors and mentee reflect on the tasks and obligations assigned and interpreted throughout the teaching practice of the EFL. Second, a research to analyse the reflection of the mentoring activity.

\section{METHODS}

\section{Research Approach}

The researcher used Mix Method. The research discusses the perspectives or views of mentee on the use of online mentoring during the COVID-19 pandemic. Respondents are students of the Faculty of Education and Teacher Training (FET2) at State Islamic University Banten, Indonesia. This university was selected because it is diverse in geography and size. This research obtained ethical approval from the academic institution of the author, and prior to participating in the research, participants signed a letter consent. The emphasis of this analysis was focused on three key questions:

RQ1. In what ways do online mentoring affect and gain the professional learning and awareness of students and enhance self-confidence?

RQ2. The Does online mentoring help preservice teacher develop similar core areas as shown in the FET2?

RQ3. How can we recognize the drawbacks of online mentorship relationships for the provision of future path enhancement?

\section{Participants}

Online survey (Google form) were sent to preservice teachers ( $\mathrm{N}=24)$ and mentors (N-4) purposively to complete the form and share their view on online learning during the pandemic. In this research, the researcher collected data from twenty-four students ( $F=9$ and $M=15)$, as sample in English Education Department who were active involve in online mentoring activities during COVID-19 pandemic. The questions were the context professional knowledge and learning, mentorship from preservice teachers, including the medium used in online mentoring, the perspective of preservice teachers on the teaching materials and the online method used in the classroom. The research was conducted from June 2020 to July 2020.

\section{Data Analysis}

Through this study, the researcher expected to find out the views of preservice teachers who practiced learning EFL as part of his teaching processes using online mentoring. Survey results were analyzed both quantitative and qualitative. A computer-generated percentage analysis of each question was formulates 
based on possible three responses to the questions (i.e. strongly agree, agree, and neutral). The qualitative results analyzed the data by identifying the themes and sub-themes, then re-write the questions and code the response. The results were represented with the help of tables and different figures.

\section{RESULTS AND DISCUSSION}

\section{Demographic Respondents}

The first question of the survey was designed to collect demographic characteristic of respondents and their experience with online mentoring. Only preservice teacher who were taking an online mentoring asked to participate. The demographic profile of participant denoting gender, age and educational disciplines as presented in Table 3. Most of the students are female (84.07\%), 38.94\% are 21-22 years old.

Table 3. Demographic profile of participants

\begin{tabular}{|l|l|l|r|}
\hline \multicolumn{2}{|l|}{} & Number & \multicolumn{1}{l|}{ Percent } \\
\hline Gender & Male & 9 & $37.50 \%$ \\
\hline & Female & 15 & $62.50 \%$ \\
\hline Age & $19-20$ & 14 & $58.33 \%$ \\
\hline & $21-22$ & 8 & $33.33 \%$ \\
\hline & Over 22 & 2 & $8.33 \%$ \\
\hline
\end{tabular}

\section{The Platform used by Preservice Teachers}

During online mentoring, mentors and mentee connected via online such as Zoom, google meet, Cisco WebEx and Microsoft team. One of the initial questions was to explore the most frequently used platforms tools, as shown in Table 2. The question was during the practicum, how often did you use application platform? The finding revealed that the platforms considered the highest number used by respondents was Zoom meeting (54\%), followed by google meet (21\%), Microsoft teams (17\%) and Cisco WebEx (8\%). The results are presented in figure1.

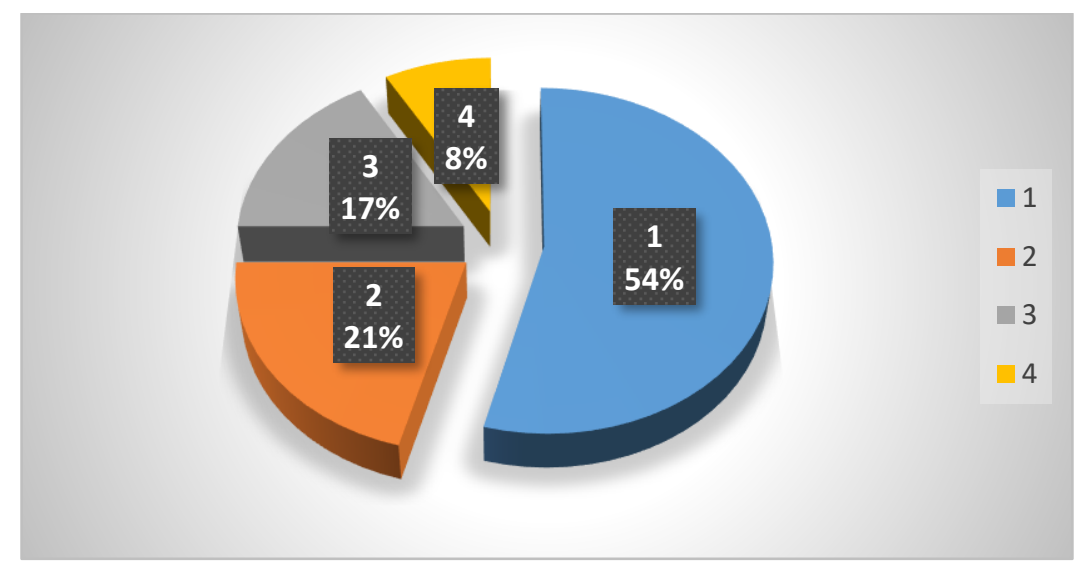

Figure 1. Distribution of Participants' Frequently usage of the platforms/devices

\section{Online Mentoring}

Responses to the question on 'lesson planning, teaching materials and students activities have changed during practicum at schools suggested that 16 respondents never change lesson plan (66\%), 7 respondents rarely change lesson plan.

Participants were also asked teaching materials and teaching approach (strategy) of online mentorship (see table 5). The responses consistently (20.8\%) and (33.3) never change, indicated that preservice teachers have positive aspects in preparing teaching materials and teaching strategies. Overall, the results show that students center activities were use during teaching and learning with $(70.8 \%)$ rarely change. 
Table 5. Preservice teachers' change lesson plans and teaching materials

\begin{tabular}{|l|r|r|r|r|r|r|}
\hline \multicolumn{1}{|c|}{ Questions } & Sometimes & \multicolumn{1}{c|}{ (\%) } & Rarely & (\%) & Never & \multicolumn{1}{c|}{ (\%) } \\
\hline Lesson plan & 1 & 4.2 & 7 & 29.2 & 16 & 66.7 \\
\hline Teaching materials & 10 & 41.7 & 9 & 37.5 & 5 & 20.8 \\
\hline Teaching approach & 3 & 12.5 & 13 & 54.2 & 8 & 33.3 \\
\hline Students-centre activity & 2 & 8.3 & 17 & 70.8 & 5 & 20.8 \\
\hline
\end{tabular}

At the end of the study, the preserve teachers were asked to complete the survey adapted from Martin and Bolliger to assess their perception of using online learning (Martin \& Bolliger, 2018). The preservice teacher indicated their extent of agreement with 5 statements on a 3-level scale (strongly agree, agree, and neutral) the questions and the results are depicted in table 7.

Analysis of the perception of preservice teachers of doing online mentoring shown that 'engage meeting and discussion virtual the highest number of respondents to be 'strongly agree' $(62.5 \%)$, followed by Classroom observation 58.3\%), professional learning from a mentor (54.2\%), and confident of my professional knowledge(45.8\%).

The result of this study was in line with the previous research that watched an evaluation of students' perception and engagement with online learning (Ituma, 2011). It was found that using online in teaching and learning were valuable in achieving the desire learning outcomes.

Table 7. Participants Perception of Mentorship

\begin{tabular}{|l|c|c|c|c|c|c|}
\hline \multirow{2}{*}{ Questions: Doing Online mentoring } & \multicolumn{2}{|c|}{ Neutral } & \multicolumn{2}{c|}{ Agree } & \multicolumn{2}{c|}{$\begin{array}{c}\text { Strongly } \\
\text { Agree }\end{array}$} \\
\cline { 2 - 7 } & $\mathbf{N}$ & $\mathbf{( \% )}$ & $\mathbf{N}$ & $\mathbf{( \% )}$ & N & (\%) \\
\hline Professional learning from a mentor & 2 & 8.3 & 9 & 37.5 & 13 & 54.2 \\
\hline Confident of my professional knowledge & 3 & 12.5 & 10 & 41.7 & 11 & 45.8 \\
\hline Classroom observation online & 2 & 8.3 & 8 & 33.3 & 14 & 58.3 \\
\hline $\begin{array}{l}\text { Engage meeting and discussion virtual } \\
\text { during mentoring }\end{array}$ & 3 & 12.5 & 6 & 25.0 & 15 & 62.5 \\
\hline Technology problem during mentoring & 9 & 37.5 & 12 & 50.0 & 3 & 12.5 \\
\hline & & & & & & \\
\hline
\end{tabular}

\section{Mentorship Expectation}

In order to analyze the mentoring and mentee expectation both groups (mentor and mentee) were asked (virtually) to define mentorship and identify their roles in the process of online mentorship (see table 7).

Table 8. Mentorship expectation

\begin{tabular}{|l|l|}
\hline Mentor roles & Role Definition \\
\hline Instructional & $\begin{array}{l}\text {-I always motivated mentee (M1) } \\
\text {-Engage students in class (M4) } \\
\text {-Motivate the students in class (M2) } \\
\text {-Consistent in all stages of teaching (M2) } \\
\text {-Using language as a medium of class (M3) }\end{array}$ \\
\hline Mentoring practices & $\begin{array}{l}\text {-In the beginning of lesson (mentee may use } \\
\text { Indonesian as welcoming) (M4) } \\
\text {-Provides feedback and professional support }\end{array}$ \\
\hline
\end{tabular}

In the term of preservice teachers' expectation from mentoring practice, the following quotes from participants' answer from the virtual survey, for example, one participant comment, "the role of the mentor as a model is very important." Regarding mentor roles, one student wrote, "mentor always motivate mentee to use target language as a medium for interaction". Using technology is a fundamental part of online mentoring, the following one of mentee, Isra, reflected on his confusion about the use of target language in the classroom by stating: 
“.. at the first meeting, I introduce the lesson in English... then ask the student to complete the exercise... but no response. I used Bahasa (Indonesian language) as medium of instruction but expected students to learn English..."

On the other hand, preservice teachers reflected on their expectation from mentor to respectful and attending online observers. Preservice teachers ask the mentor about teaching ideas and providing teaching assistance. Mentee practices haw to be successful and careful students, open to changes and act flexible in term of teaching and learning process.

\section{CONCLUSIONS}

This study found that an online mentoring experience positively impacted the mentoring of EFL teaching in Banten. The mentee found the online mentoring format to be manageable overall; they strengthened their understanding of "true" classroom interactions and received inspiring and encouraging guidance from experienced teachers. In terms of practical consequences, this study has shown the value of the setting up and encouraging mentorship program to create an accelerated the process of professional learning.

This study in line with Brisco's finding that mentee seemed to benefit from the mentoring program independently of the mentor's individual mentoring style (Briscoe, 2019), and it also confirms Ericron's finding (Ericsson, 2006) that increasing the level of involvement of the preservice teachers in the knowledge construction process. In this case, mentoring can accelerate the growth of their expertise from the beginning. Considering the conflicting tension during online mentoring practice, EFL preservice teachers programs need to ensure that effective practice teaching experiences are provided.

A mentorship program, embedded in teacher education institution is a promising alternative for influencing preservice teachers in the early stages of their careers, creating a dedication to professional learning and minimizing turnover and burnout rates of teacher through enhancing well-being among future teachers.

By using a learner-to-expert approach to recognizing how prospective teacher candidates can improve their skills by learning about teaching and acquiring experiential professional experience that they will not acquire from textbooks on their own, in the early stages of their career, new teachers will feel more equipped to meet the challenges of work and have the tools they need to be promoted.

COVID-19 pandemic has forced universities to understand the importance of online mentoring for preservice teachers. The experience of students with online mentoring was comparable with those of previous research. In addition to acquiring information, the present study revealed the effect of online mentoring on preservice teachers' morale by providing a distraction from the current COVID-19 pandemic. It can be inferred that online is feasible and needs to be a part of Indonesians' undergraduate teacher training. Supports from institution and government are needed for the success of online learning. The next research would be to engage in a broader study seeking gender differences in designing online mentoring materials and the roles and responsibilities of mentors.

\section{ACKNOWLEDGEMENT}

The researcher gratefully acknowledges the participant support for this study is from the faculty of State Islamic University Banten, Indonesia, who contributed to this research during COVID-19 Pandemic.

\section{REFERENCES}

Abere, O. (2020). Survival Analysis of Novel Coronavirus ( 2019-nCov ) Using Nelson Aalen Survival Estimate . International Journal of Finance, Accounting and Corporation, 1(1), 17-24.

Awaya, A., McEwan, H., Heyler, D., Linsky, S., Lum, D., \& Wakukawa, P. (2003). Mentoring as a journey. Teaching and Teacher Education. https://doi.org/10.1016/S0742-051X(02)00093-8

Brandt, J.-O., Barth, M., Merritt, E., \& Hale, A. (2020). A matter of connection: The 4 Cs of learning in preservice teacher education for sustainability. Journal of Cleaner Production, 279, 123749.

Briscoe, P. (2019). Virtual mentor partnerships between practising and preservice teachers: Helping to enhance professional growth and well-being. International Journal of Mentoring and Coaching in Education, 8(4). https://doi.org/10.1108/IJMCE-02-2019-0023

Bubb, S. (2005). Helping teachers develop. SAGE.

Carliner, S. (2004). An overview of online learning (Second). Human Resource Development Press Inc.

Carliner, S., \& Shank, P. (2016). The e-learning handbook: past promises, present challenges. John Wiley \& Sons.

Chapelle, C., \& Jamieson, J. (2008). Tips for teaching with CALL: Practical approaches to computer-assisted 
language learning. Pearson Education.

Cox, E., Bachkirova, T., \& Clutterbuck, D. A. (2014). The complete handbook of coaching. Sage.

Darling-hammond, L., Hyler, M. E., \& Gardner, M. (2017). Eff ective Teacher Professional Development. June.

Delaney, Y. A. (2012). Research on Mentoring Language Teachers : Its Role in Language Education. 45, 184202. https://doi.org/10.111/j.1944-9720.2012.01185.x.FOREIGN

Demuyakor, J. (2020). Coronavirus (COVID-19) and Online Learning in Higher Institutions of Education: A Survey of the Perceptions of Ghanaian International Students in China. Online Journal of Communication and Media Technologies, 10(3), e202018. https://doi.org/10.29333/ojcmt/8286

Devies, A. and M. K. (2002). Materials evaluation and design for language teaching. Edinburgh University Press.

Dudeney, G. and Hockly, N. (2008). How to Teach English with Technology. London: Longman.

Ericsson, K. A. (2006). Protocol analysis and expert thought: Concurrent verbalizations of thinking during experts' performance on representative tasks. In The Cambridge handbook of expertise and expert performance.

Farrell, T. S. C. (2008). Here's the book, go teach the class' ELT practicum support. RELC Journal, 39(2), 226241. https://doi.org/https://doi.org/10.1177/0033688208092186

Fithra, H. (2020). Covid-19 and Online Learning. Mediaindonesia. https://doi.org/https://mediaindonesia.com/read/detail/298964-covid-19-dan-pembelajarandaring

Funk, F. F., Hoffman, J. L., Keithley, A. M., \& Long, B. E. (1982). Student teaching program: Feedback from supervising teachers. The Clearing House, 55(7), 319-321.

Greenberg, M. T., Brown, J. L., \& Abenavoli, R. M. (2016). Teacher stress and health effects on teachers, students, and schools. In Edna Bennett Pierce Prevention Research Center, Pennsylvania State University.

Gross, M. (2020). Virus outbreak crosses boundaries. Current Biology, 30(5), R191-R194. https://doi.org/10.1016/j.cub.2020.02.049

He, K., Stolarski, A., Whang, E., \& Kristo, G. (2020). Addressing General Surgery Residents' Concerns in the Early Phase of the COVID-19 Pandemic. Journal of Surgical Education. https://doi.org/10.1016/j.jsurg.2020.04.003

Hennissen, P., Crasborn, F., Brouwer, N., Korthagen, F., \& Bergen, T. (2011). Author 's personal copy Clarifying pre-service teacher perceptions of mentor teachers ' developing use of mentoring skills. Teaching and Teacher Education, 27, 1049-1058. https://doi.org/10.1016/j.tate.2011.03.009

Hobson, A. J., Ashby, P., Malderez, A., \& Tomlinson, P. D. (2009). Mentoring beginning teachers: What we know and what we don't. Teaching and Teacher Education. https://doi.org/10.1016/j.tate.2008.09.001

Hyndman, B. P., \& Harvey, S. (2020). Preservice teachers' perceptions of Twitter for health and physical education teacher education: A self-determination theoretical approach. Journal of Teaching in Physical Education, 39(4), 472-480.

Ituma, A. (2011). An evaluation of students' perceptions and engagement with e-learning components in a campus based university. Active Learning in Higher Education, 12(1), 57-68. https://doi.org/10.1177/1469787410387722

Izadinia, M. (2015). A closer look at the role of mentor teachers in shaping preservice teachers' professional identity. Teaching and Teacher Education. https://doi.org/10.1016/j.tate.2015.08.003

Kearsley, G., \& Shneiderman, B. (1998). Engagement theory: A framework for technology-based teaching and learning. Educational Technology, 38(5), 20-23.

Kutsyuruba, B., \& Walker, K. D. (2020). The Role of School Administrators in the Induction and Mentoring of Early Career Teachers. In Oxford Research Encyclopedia of Education.

Lacey, K. (1999). Developments in Mentoring, Making Mentoring Happen. In Business \& Professional Publishing Pty Ltd.

Malanson, K., Jacque, B., Faux, R., \& Meiri, K. F. (2014). Modeling for fidelity: Virtual mentorship by scientists fosters teacher self-efficacy and promotes implementation of novel high school biomedical curricula. PloS One, 9(12), e114929.

Malderez, A., \& Wedell, M. (2007). Teaching teachers: Processes and practices. A\&C Black.

Mann, S., \& Tang, E. H. H. (2012). The role of mentoring in supporting novice English language teachers in Hong Kong. Tesol Quarterly, 46(3), 472-495.

Martin, F., \& Bolliger, D. U. (2018). Engagement matters: Student perceptions on the importance of engagement strategies in the online learning environment. Online Learning Journal, 22(1), 205-222. https://doi.org/10.24059/olj.v22i1.1092

Murphy, M. P. A. (2020). COVID-19 and emergency eLearning: Consequences of the securitization of higher 
education for post-pandemic pedagogy. Contemporary Security Policy, 41(3), 492-505. https://doi.org/10.1080/13523260.2020.1761749

Owen, H., \& Whalley, R. (2017). A journey from within: the virtual mentoring CASE model. Journal of Advances in Education Research, 2(4), 253-264.

Peterson, B. E., Williams, S. R., \& Dunham, P. H. (1998). Connecting Research to Teaching: Mentoring Beginning Teachers. The Mathematics Teacher, 91(8), 730-734.

Pollard, A., \& Collins, J. (2005). Reflective teaching. A\&C Black.

Powell, R. R., \& Mills, R. (1994). Five Types of Mentoring Build Knowledge on Interdisciplinary Teams. Middle School Journal, 26(2), 24-30. https://doi.org/10.1080/00940771.1994.11494406

Pyne, C. (2014). A quality education begins with the best teachers. The Sunday Morning Herald. https://www.smh.com.au/politics/federal/a-quality-education-begins-with-the-best-teacherssays-christopher-pyne-20140219-32z61.html

Reese, J. (2016). Virtual mentoring of preservice teachers: Mentors' perceptions. Journal of Music Teacher Education, 25(3), 39-52.

Riazi, A. M. (2003). What do textbook evaluation schemes tell us?: A study of the textbook evaluation schemes of three decades. In Methodology and materials design in language teaching: Current perceptions and practices and their implications (pp. 52-69). SEAMEO Regional Language Centre.

Shyamlee, S. D., \& Phil, M. (2012). Use of technology in English language teaching and learning: An analysis. International Conference on Language, Medias and Culture, 33(1), 150-156.

Simamora, R. M. (2020). The Challenges of Online Learning during the COVID-19 Pandemic: An Essay Analysis of Performing Arts Education Students. Studies in Learning and Teaching, 1(2), 86-103. https://doi.org/https://doi.org/10.46627/silet.v1i2.38

Smith, T. M., \& Ingersoll, R. M. (2004). What are the effects of induction and mentoring on beginning teacher turnover? In American Educational Research Journal. https://doi.org/10.3102/00028312041003681

Tasnim, Z. (2020). Concept of Mentoring : An Effective Means of Teachers "Professional Growth. 4(5), 74-77.

Tomlinson, P. (1998). Understanding mentoring: Reflective strategies for school-based teacher preparation. Open Univ. Press.

Tuomikoski, A., Ruotsalainen, H., Mikkonen, K., Miettunen, J., Juvonen, S., Sivonen, P., \& Kääriäinen, M. (2020). How mentoring education affects nurse mentors' competence in mentoring students during clinical practice-A quasi-experimental study'. Scandinavian Journal of Caring Sciences, 34(1), 230238.

UNESCO. (2020). 290 million students out of school due to COVID-19. https://en.unesco.org/news/290million-students-out-school-due-covid-19-unesco-releases-first-global-numbers-and-mobilizes

W.H.O. (2020). Coronavirus disease (COVID-19) pandemic. https://www.who.int/emergencies/diseases/novel-coronavirus2019?gclid=EAIaIQobChMIspa91snl6wIVgnwrCh0PXQfQEAAYASAAEgKt6PD_BwE

World bank. (2018). World Bank Education Overview: Teachers. World Bank. https://documents.worldbank.org/en/publication/documents-

reports/documentdetail/555631541081210478/world-bank-education-overview-teachers

Wright, T. (2008). How to be a brilliant teacher. In How to Be a Brilliant Teacher. https://doi.org/10.4324/9780203870778

Yang, Y., Peng, F., Wang, R., Guan, K., Jiang, T., Xu, G., Sun, J., \& Chang, C. (2020). The deadly coronaviruses: The 2003 SARS pandemic and the 2020 novel coronavirus epidemic in China. Journal of Autoimmunity, 102434.

Yulia, H. (2020). Online Learning to Prevent the Spread of Pandemic Corona Virus in Indonesia. ETERNAL (English Teaching Journal), 11(1). 